\title{
The Effect of one Course of Swimming Exercise before Induction of Multiple Sclerosis (MS) on Nerve Growth Factor Levels in Rat's Brain
}

\author{
Hamid Hosseini $^{1}$, Zia Fallah Mohammadi ${ }^{2}$ \\ 1. Master of Exercise Physiology, Department of Sport Physiology, Faculty of Physical Education and Sport Science, \\ University of Mazandaran, Babolsar, Iran., (Corresponding Author), Tel: 056-32504995, Email: hosseini.h1990@gmail.com, \\ ORCID ID: 0000-0003-3886-6363 \\ 2. Associate Professor, Department of Sport Physiology, Faculty of Physical Education and Sport Science, University of \\ Mazandaran, Babolsar, Iran. ORCID ID: 0000-0002-9214-0195
}

\begin{abstract}
Background and Aim: Multiple Sclerosis is a chronic inflammatory disease with unknown etiology in the nervous system. However, exercise routinely for these patients is beneficial, but the effect of pretreatment swimming exercise in this disease has not been fixed. Therefore, the aim of these study was to investigate pretreatment effect of swimming exercise on NGF levels in female Lewis rats with experimental autoimmune encephalomyelitis.

Materials and Methods: This experimental in vitro study was conducted on female Lewis rats. In this study, animals were randomly divided into 4 groups (each group 5), including healthy control, EAE control, healthy swimming and EAE swimming. The training protocol included swimming exercise 1 hour/day, 5 days/week for six weeks.

Results: This study shows that NGF levels in EAE swimming group were significantly increased compared to the same controls $(\mathrm{P}=0.006)$. Also the weight of EAE swimming training group significantly increased compared with control $(\mathrm{P}=0.001)$.

Conclusion: According to these findings, concluded that pretreatment with sub-chronic swimming exercise, through increased levels of NGF, is effective in inhibiting EAE. Hence, perhaps, the protocol used in this study to enhance the protection of nerve cells in the brain tissue of MS Risk Factors and ultimately recommended to promote brain health.
\end{abstract}

Keywords: Multiple sclerosis, Swimming exercise, Nerve growth factor

Received: June 19, 2019

Accepted: July 9, 2019

\footnotetext{
How to cite the article: Hamid Hosseini, Zia Fallah Mohammadi. The Effect of one Course of Swimming Exercise before Induction of Multiple Sclerosis (MS), on Nerve Growth Factor Levels in Rat's Brain. SJKU 2020;25(2):27-36.

Copyright (C) 2018 the Author (s). Published by Kurdistan University of Medical Sciences. This is an open access article distributed under the terms of the Creative Commons Attribution-Non Commercial License 4.0 (CCBYNC), where it is permissible to download, share, remix, transform, and buildup the work provided it is properly cited. The work cannot be used commercially without permission from the journal
} 


\section{اثر يك دوره فعاليت ورزشى شنا يِ از القاى مالتيّل اسكلروزيس بر سطوح فاكتور رشد عصبى در مغز موشصحرايى}

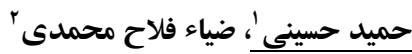

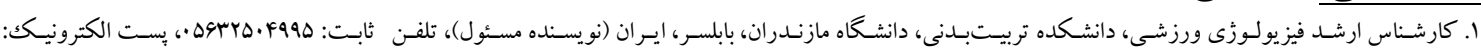
…....r-rMA_Grarseini.h1990@gmail.com

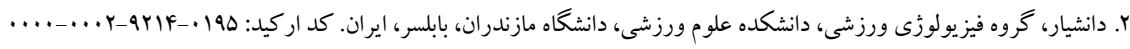

جكيله

زمينه و هدف: بيمارى مالتيّل اسكلروزيس (MS; Multiple Sclerosis) يكك بيمارى التهابى مزمن با اتيولوزى نامشخص

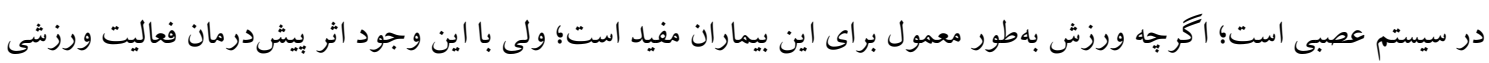

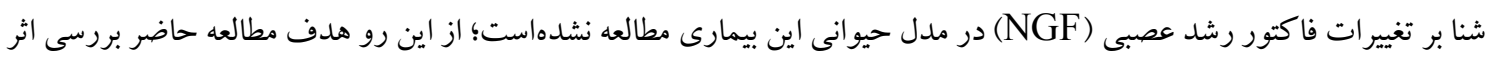

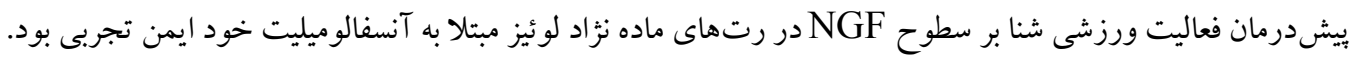

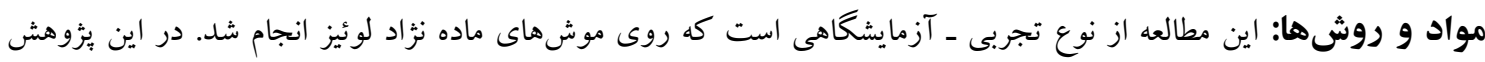

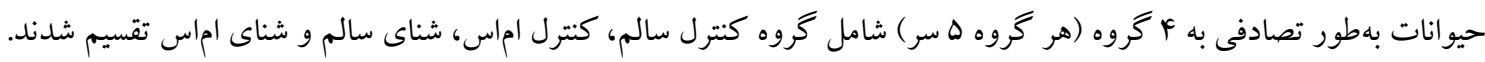

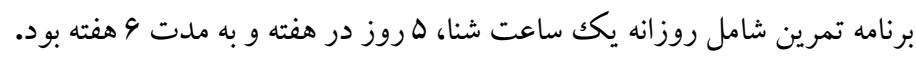
يافتهها: نتايج اين مطالعه نشان مىدهد كه سطوح NGF در گرووه تمرين شناى اماس نسبت به كنترل بهطور معنىدارى افزايش

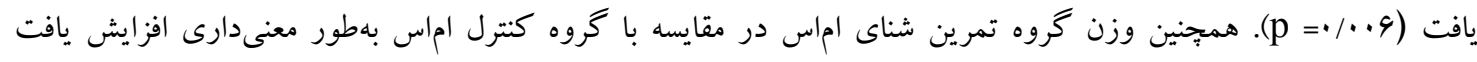
$(\mathrm{p}=\cdot / \cdot \cdot 1)$ نتيجه كيرى: با توجه به يافتهاى بُزوهش مىتوان جنين نتيجه گرفت كه احتمالاً بيش آمادهسازى با تمرينات ميانمدت شنا، از

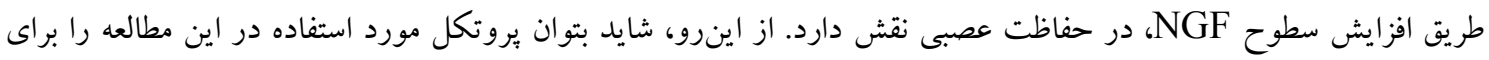

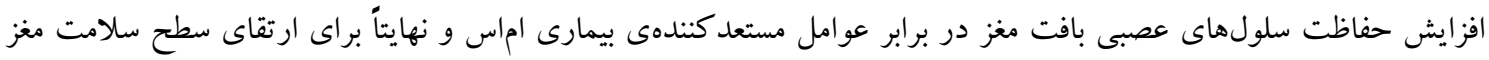
توصيه كرد. كلمات كليدى: مالتييل اسكلروزيس، تمرين شنا، فاكتور رشد عصبى

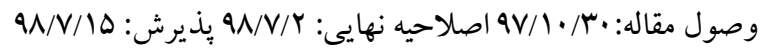


نوروتروفيك مشتق از مغز (BDNF) است(ه). در مطالعهاى كه توسط Cotman و همكاران (r...r) انجام شد، مشاهده شد كه تمرين ورزشى باعث افزايش بيان فاكتورهاى نوروتروفيك از جمله BDNF و NGF در هييو كامٍ دو مدل حيوانى مايس و رت مىشود(·1). همجنين در تحقيقى كه توسط Bernardes و همكاران

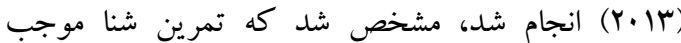
افزايش ميزان عوامل نوروتروفيك در مغز، از جمله فاكتور

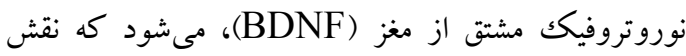
مهمى در ميلينسازى دارد(11). نتيجه تحقيق عسكرى و

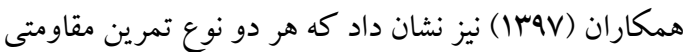
و تمرين در آب، از طريق افزايش سطوح بلاسمايى و بيان زن نوروتروفين-rا، باعث بهبود علائم مبتلايان به اماس

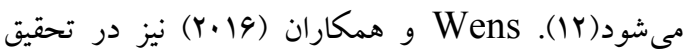
خود گزارش كردند كه بعد از YF هفته تمرين استقامتى و مقاومتى غلظت BDNF در بيماران مبتلا به اماس با افزايش معنىدارى مواجه شد(r)). در اين زمينه همجنين نتايج تحقيق Chae و همكاران (Y...9) نشان داد كه مقادير NGF دويدن روى تردميل، بهطور معنىدارى افزايش يافت(If). اين محققين همجنين در مطالعه خود (Yll) نشان دادند كه

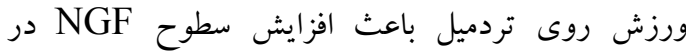
رتهاى ديابتى شده و از اين طريق از آيويتوز سلول برد

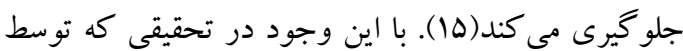

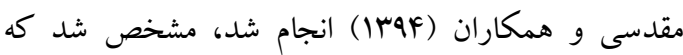
تمرينات مقاومتى به مدت م هفته و r جلسه در هفته، موجب

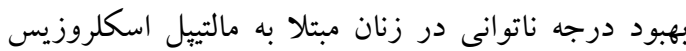
شده؛ اما تأثيرى بر NGF آنها نداشت(19). مطالعات ذكر شده عموماً بعد از ابتلاى فرد به بيمارى از ورزشهاى بهاى

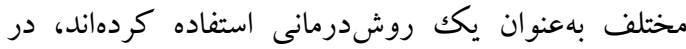

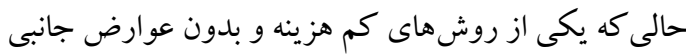

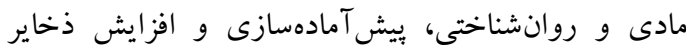

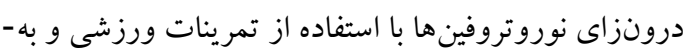

مقدمه مالتييل اسكلروزيس (اماس) يكك بيمارى التهابى در سيستم عصبى مركزى است كه غلاف ميلين را دركير كرده و باعث تخريب آن مىشود. اين بيمارى در بزر گكسالان جوان

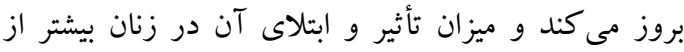
مردان است(1). اتيولوزى اين بيمارى مشخص نيست؛ ولى فاكتورهاى محيطى و زنتيكى در استعداد ابتلا به بيمارى نقش دارند(Y). خستخى، ضعف عضلانى، فلج خفيف و اسباسم از علائم شايع اين بيمارى است(ب). در حال حاضر هيج درمانى كه تأثير اثبات شدهاى در توقف بيمارى داشته

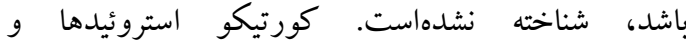
آدرنو كورتيكوترويين و اينترفرونها، بهعنوان داروهاى ضد التهاب مورد استفاده قرار مى گيرند. با توجه به عدم درمان

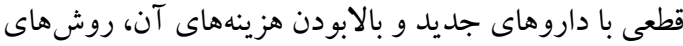
غير دارويى از جمله ورزش، مىتواند مؤثرتر بوده و به راحتى توسط بيماران، مورد قبول واقع شود(א). از سوى ديخر بُزوهشها حاكى از آن است كه توسعه و عملكرد عادى نورونها بهحضور نوروتروفينها بستخى دارد. در اين بين، فاكتور رشد عصبى (NGF) كه در سال • 190 كشف شد(ه)، بهعنوان نماينده و اولين عضو جدا شده و بهترين توصيف از يكك خانواده در حال رشد از نوروتروفينها بوده

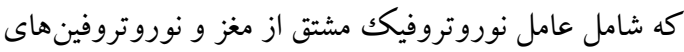
ه-r است(9). اين خروتئين باعث تمايز، توسعه و بقاء نورونها در سيستم عصبى محيطى و مركزى مىشود (V).

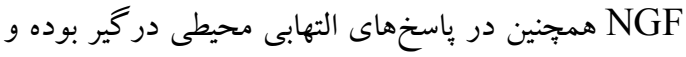
نقش مهمى نيز در باتوزُنز عصبى ايفا مى كند. علاوه بر اين، وجود NGF در مغز باعث جلو گيرى از انحطاط سلولهاى عصبى كولينرزيك آسيبديده، افزايش فعاليت سلولهاى عصبى كولينرزيكك سالم و بهبود اختلالات فضايى در موشهاى مسن مىشود(1). از طرفى، نتايج برخى مطالعات

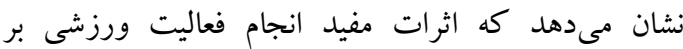
عملكرد مغز تا حدى به واسطه تقويت عملكرد و افزايش اتش سطوح نوروتروفينها بخصوص NGF و فاكتور 
تمرين شنا را انجام دادند و پِ از آن مخلوطى از سم عصبى ادجوانت و نخاع خو كجه به آنها تزريق شد (كروه تمرين شناى اماس). هر گروه شامل هـ سر موش بود؛ كه به اله صورت هـ سر موش در هر قفس يلىكربنات شفاف و در

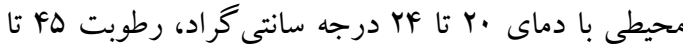

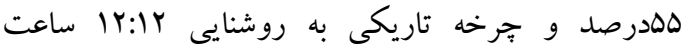
نخهارى شدند. در طى دوره يُروهش نيز حيوانات از غذاى ساخت شركت بهيرور بهصورت بلت و بلهصورت آزاد مصرف كردند. در ضمن آب مورد نياز حيوانات آزادانه و از طريق بطرىهاى ويزه در دسترس قرار داده شد (جدول

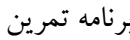
قبل از اجراى برنامه تمرينى، بهنظور آشنايى با آب و كاهش استرس شنا و ساز كارى با شرايط تمرينى، موشها

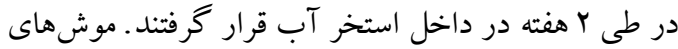
صحرايى ماده نزاد لوييز، يككبار در روز و ينج روز در

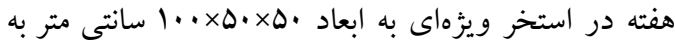
شنا برداختند. برنامه اصلى تمرين با •r دقيقه آغاز شد كه اين مدت با افزايش ينج دقيقه روزانه به زمان تمرين، در هفته دوم به •9 دقيقه رسيد. زمان •9 دقيقه تا بايان هفته ششم ثابت بود. اضافه بار تمرينى از طريق تنظيم قدرت و

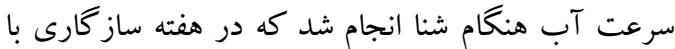
9. تمرين، ثابت بود. در هفتهاى تمرين با ثابت ماندن دقيقه، سرعت و قدرت جريان آب از Vليتر به •r ليتر در لهرين دقيقه افزايش يافت(IV) (IV). نحوه القاء EAE به منظور القاء EAE در حيوانات از مخلوطى از نخاع خو كجه و سم عصبى ادجوانت استفاده شد. بدين منظور ابتدا ها سر خو كجه هندى از موسسه تحقيقات واكسن و سرمسازى رازى كرج خريدارى شده و به آزمايشكاه منتقل شدند. FF ساعت پِ از آخرين وهله تمرين هر يكك از اين

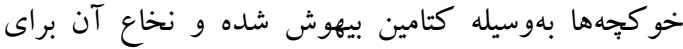
انجام مراحل بعدى آزمايش بيرون آورده شد. بـ از بيرون
ويزٔه شنا است. احتمالاً اين رويكرد موجب افزايش ضريب مقاومت نرونها در برابر عوامل باتوزنز بيمارى اماس نيز مى گردد. با توجه به اينكه مطالعات اندكى به بررسى تأثير

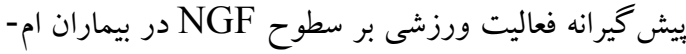
اس و نيز مدل القا شده حيوانى آن، يعنى آنسفالوميليت خودايمن تجربى، برداختهاند و تحقيقات اندك انجام شده

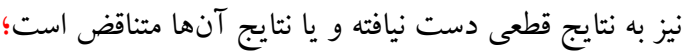
لذا بر اين اساس، يزوهش حاضر در نظر دارد تا به بررسى تأثير فعاليت بيش گيرانه يكك دوره تمرينات شنا بر سطوح

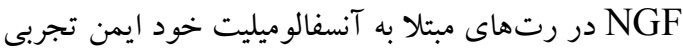

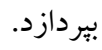

مواد و روشها آزمودنى ها و محيط يُزوهش ونه

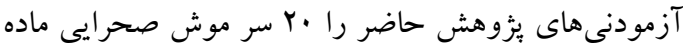

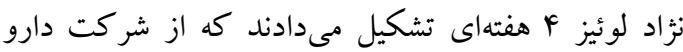

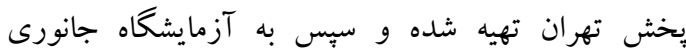

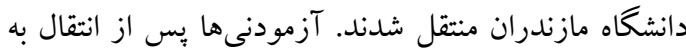

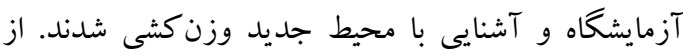

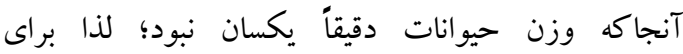

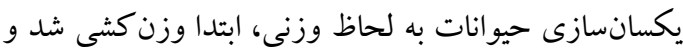

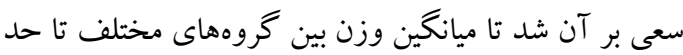

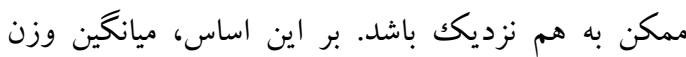

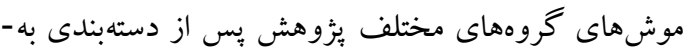

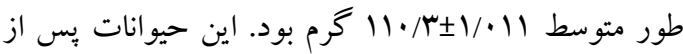

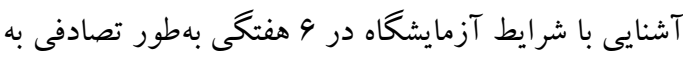

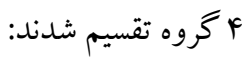

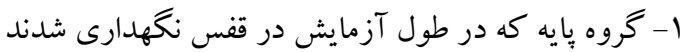

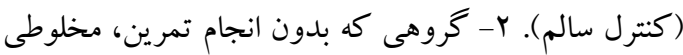
از سم عصبى ادجوانت و نخاع خو كجه هندى (به منظور القاء EAE) دريافت كردند (كنترل اماس) r- گروهى كه در طول آزمايش فقط تمرين شنا را انجام دادند (كروه

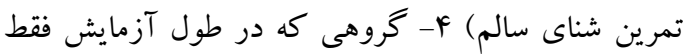




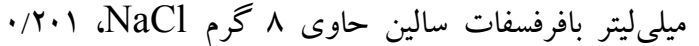
كرم

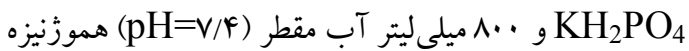
شد و سبس محلول بهدست آمده از آن به مدت · ا دقيقه و

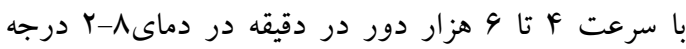
سانتى گراد سانتريفيوز شد و براى سنجش شاخص مورد نظر با استفاده از يخ خشك به آزمايشكاه منتقل شد. براى تعيين

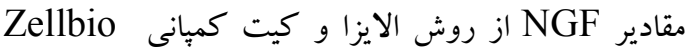
chemical (company, German) حساسيت كيت ng/ml r • ب. بود. تجزيه و تحليل دادهها بِ از جمع آورى دادههاى خام، از آمار توصيفى براى دهاى دستهندى دادها و تعيين شاخص هاى مر كزى و ير إكند استفاده شد. با توجه به طبيعىبودن نحوه توزيع دادهها، از Ong ANOVA) روش تحليل واريانس يككطرفه (Way و آزمون تعقيبى توكى (TUKEY) بهنظور بررسى تفاوت شاخص NGF بين گرووهاى مختلف يُزوهش استفاده شد. براى تجزيه و تحليل آمارى از نرمافزار

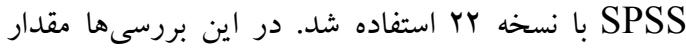
معنى دارى (PS/ P (P) در نظر كرفته شد.

\section{يافته ها}

بر اساس يافته هاى جدول شماره ا مشاهده مىشود كه وزن

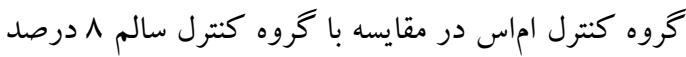

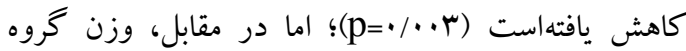
تمرين شناى اماس نسبت به كروه كنترل اماس به ميزان 9

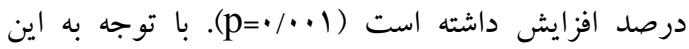
يافتها بهنظر مىرسد كه تمرين ورزشى شنا قادر است از كاهش وزن ناشى از القاء سم عصبى جلو گيرى كند.
آوردن نخاع خوكجه و منتقل كردن آن بهداخل ميكروتيوب، بهمنظور فريز كردن بافت (نخاع خو كجه)، آن

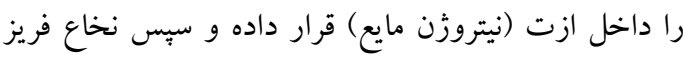
شده دو مرتبه در هاون ير از ازت قرار دادهشد و درحالى كه إنه

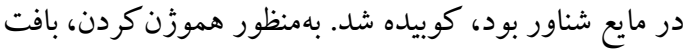
كوبيدهده را با نسبت برابر با سالين مخلوط كرده و در دماى F درجه سانتى گراد در دستگاه شيكر قرار داده تا تان

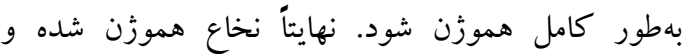
ادجوانت خريدارى شده از شركت سيگما را با نسبت البه 1 مخلوط كرده و بعد از بـهوش كردن حيوانات به وسيلهى كتامين (V. mg/kg; Alfasan, Holland)، بههر حيوان

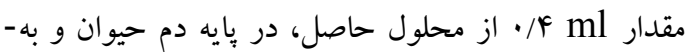
صورت درون صفاقى، تزريق شد(1)). روند بيمارى و تغيير

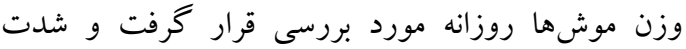

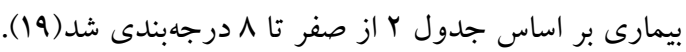
با توجه به جدول مذكور، جنانجه به هريك از حيوانات امتياز ناتوانى ا تا م داده مى شد نشاندهنده ابتلاى حيوان به

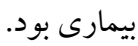
بافت بردارى و تجزيه و تحليل آزمايشكاهى بودي

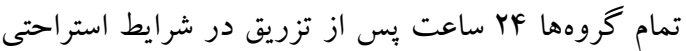

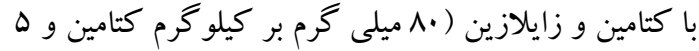

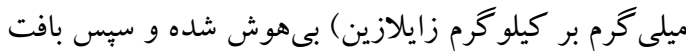
مغز حيوان جدا و يس از شستوشو بلافاصله در مايع نيتروزن قرار داده شد و سبس تا زمان هموزنيزه شدن (بهوسيله دستگاه هموزنايزر مدل IKA MS 3D digital

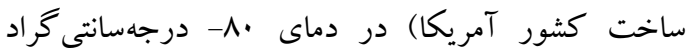
ذخيرهسازى شد(1). جهت سنجش غلظت NGF بافت مغز، ابتدا بافت مغز با استفاده از مايع نيتروزن يودر شده و

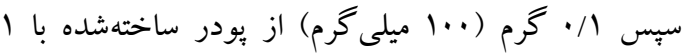




\begin{tabular}{|c|c|c|}
\hline ميانكين وزن هايان & ميانكين وزن ابتداى يثوهش & نام كروه \\
\hline$r \cdot \Delta / \Lambda \pm \xi / / F$. & $11 \cdot \pm / 4 \& q$ & كنترل سالم \\
\hline $19 \cdot \pm \pi / 1 r r$ & $11 \cdot / 9 \pm / 1 \mathrm{IV}$ & * كنترل اماس \\
\hline$r \mid \Delta / r \pm r / F r \Lambda$ & $1 \cdot 9 / r \pm / r \cdot F$ & تمرين شناى سالم \\
\hline$r \cdot V / 4 \pm N / q V V$ & $111 / 9 \pm / \wedge 1 V$ & تمرين شناى اماس \\
\hline$r \cdot F / 9 \pm \cdot / \Delta G F$ & $11 \cdot / r \pm / .11$ & مجموع \\
\hline
\end{tabular}

جدول r. درجهبندى شدت بيمارى بر اساس علائم و بيامدهاى ناشى از القاء EAE

\begin{tabular}{|c|c|}
\hline علائم و يِيامدها & درجه شدت بيمارى \\
\hline عدم ابتلا به بيمارى & . \\
\hline اختلال در حر كت دم & 1 \\
\hline فلج شدن دم & r \\
\hline اختلال ملايم در راه رفتن & $r$ \\
\hline اختلال شديد در راه رفتن & f \\
\hline فلجى يك پا & $\Delta$ \\
\hline فلجى هر دو يا & 9 \\
\hline فلجى كامل دست و پيا & v \\
\hline 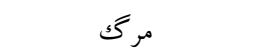 & $\wedge$ \\
\hline
\end{tabular}

يـروتئين در بافـت مغـز شـدهاسـت. از سـوى ديخـر، درصــ

تغييرات سطح NGF در كروه تمـرين شـناى اماس ( II/F

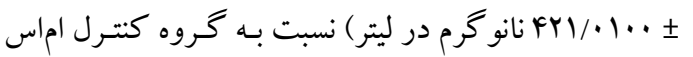

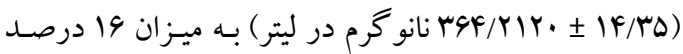

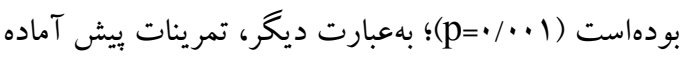

سازى شنا موجب حفظ ذخاير NGF مغز حيوانات گرديد.
نمودار ا ميانگين سطوح NGF را در گروههـاى مختلـف

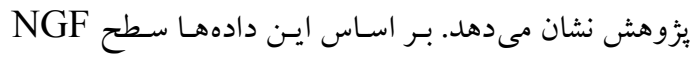
آزمودنىهاى گروه كنترل اماس نسبت به گروه كنترل سـالم

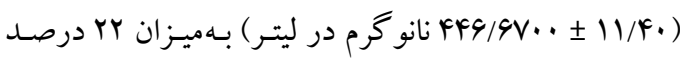

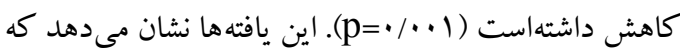
القـاء EAE (كـه شـامل محلـولى از نخــاع خو كجِهـ و سـم عصبى ادجوانت است) موجب كاهش قابل توجه مقدار ايـن 


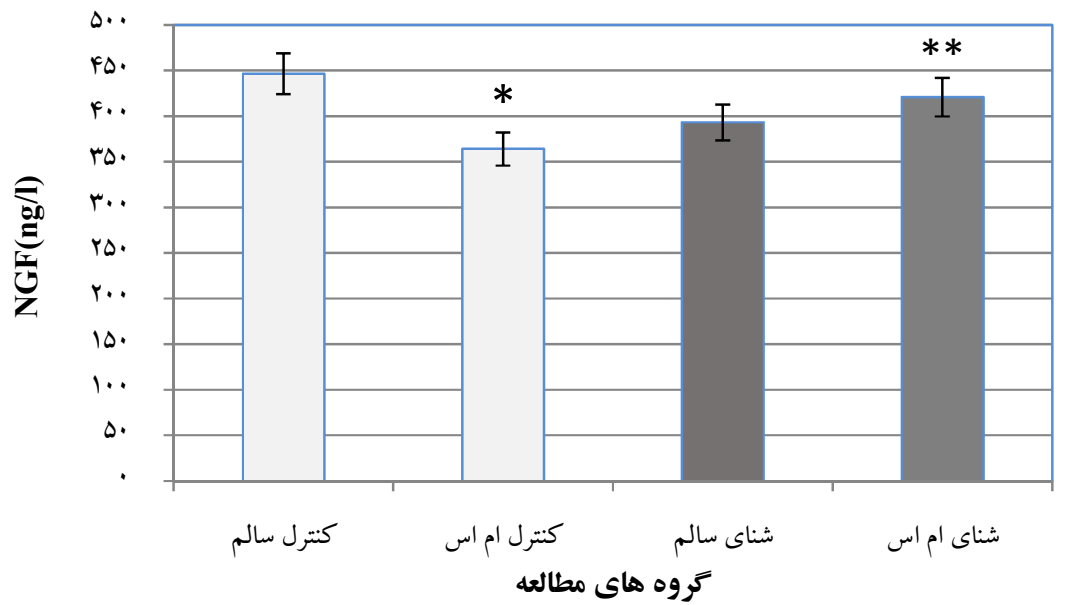

نمودار ا. ميانكين سطوح NGF مغز در كروههاى مختلف ئوهش.

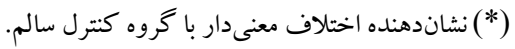

(*) نشاندهنده اختلاف معنى دار با كنترل اماس.

همكاران (Y.... اشاره كرد. در اين مطالعه محققين مقادير سرمى بايه و واكنشيذيرى فاكتور رشد عصبى (NGF) و مهمترين يافته مطالعه حاضر نشاندهنده جلو گيرى قابل فاكتور نروتروفيك مشتق از مغز (BDNF) به ورزش حاد توجه و معنىدار از كاهش سطح فاكتور رشد عصبى استاندارد را بررسى كردند. نتيجه اين مطالعه نشان داد كه (NGF) سطوح NGF يس از •r دقيقه فعاليت هوازى در بيماران بهطور كلى نتايج بهدست آمده نشان مىدهد كه انجام فعاليت اماس افزايش يافت. محققين در اين مطالعه عنوان كردند كه ورزشى شنا داراى اثر حفاظتى در مقابل بيمارى اماس است. سطوح افزايش يافته NGF با شدت بيمارى در ارتباط بهنظر مىرسد ورزش شنا مىتواند به واسطه تأثير افزايشى است(Yr). علاوه بر اين Patel و همكارش (rا. (Y) نيز در روى عوامل نروتروفيك،، از جمله NGF، يك عامل تحقيقى با هدف بررسى تأثير ده روز ورزش اجبارى روى حفاظت عصبى در برابر بيمارى اماس باشد. مشخص شدهتردميل بر فاكتورهاى نروتروفيك در حيوانات مبتلا به است كه ورزش مىتواند در مسير توليد NGF به واسطة آنسفالوميليت خودايمن تجربى، به اين نتيجه رسيدند كه افزايش انرزى در دسترس سلولهاى عصبى و بلوغ سطوح NGF در گروههاى ورزشى نسبت به گرووهاى نهاى كنترل به طور معنىدارى افزايش يافت(T/). همجنين يشيشازهاى NGF و نيز افزايش بيان تيروزين كيناز T (TrKA) Chae

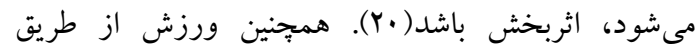
ورزش روى تردميل باعث بهبود عملكرد شناختى و تسهيل افزايش بيان گيرندهى NGF در سطح سلول، اثربخشى اين سيخنالينگ فاكتور رشد عصب، بهوسيله فعال كردن برودئئين

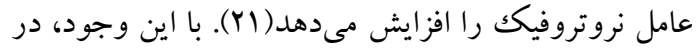

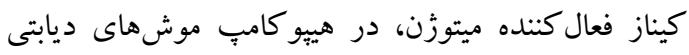

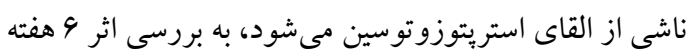

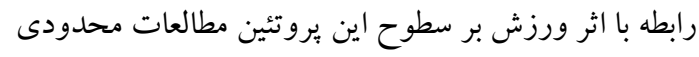

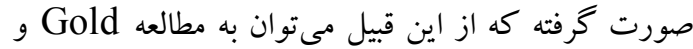


لازم است شدت و مدت تمرينات افزايش يابد(YD).

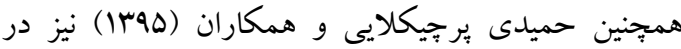
مطالعه خود به بررسى اثر حفاظتى جهار هفته تمرين روى نوار كردان همراه با مصرف مكمل ويتامين D3 بر سطح عامل رشد عصبى در جسم مخاط موشهاى ياركينسونى

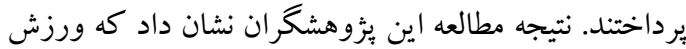
بهتنهايى نمىتواند سطوح NGF را بهطور معنىدارى افزايش دهد. آنها عنوان كردند كه احتمالاً انجام تمرينات ورزشى استقامتى، جه از نوع اجبارى و جّه اختيارى، لازم

است از نظر مدت طولانى تر از جهار هفته اجرا شود(Y4). با عنايت به مطالب فوق، اين گونه به نظر مىرسد كه؛ تفاوت در نوع تمرين (اجبارى يا اختيارى)، شدت و مدت تمرين

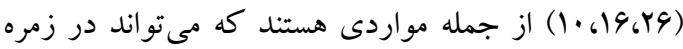
علل تفاوت در نتايج يزوهشها باشد. همجنين از آنجا كه مقادير سرمى NGF با مقادير آن در بافت مغز الزاماً برابر نيست و از طرفى در نمونه هاى انسانى سطوح سرمى متغير وابسته اندازهگيرى مىشود و حال آنكه در نمونه حيوانى اندازهگيرى مستقيماً از بافت مغز انجام مىشود؛ لذا نوع آزمودنى نيز مىتواند يكى ديخر از جمله دلايل اختلاف نتايج يزوهش حاضر با برخى يثوهش ها باشد. علاوه بر اين، از ديخر دلايل احتمالى اين اختلاف مىتوان به اين موضوع اشاره كرد كه مطالعه حاضر از نوع بيشدرمان بود، يعنى ابتدا بروتكل ورزشى اجرا شده و سيس مدل تجربى بيمارى توليد شد كه اين نيز مىتواند روى نتايج بزوهش اثر خذار باشد؛ بنابراين به نظر مىرسد كه تمرين ورزشى شنا مىتواند از كاهش سطوح NGF بر اثر القاى سم عصبى ادجوانت، در حيوانات مبتلا به آنسفالوميليت خودايمن تجربى، جلو گيرى كند. در پيايان مىتوان كفت يُوهشها در زمينه تأثير شيوههاى متفاوت تمرين بر سطوح NGF محدود است و نتايج مطالعات نيز متفاوت است. از سوى ديخر فشار و استرس ايجاد شده در حين تمرين در آب، از جمله محدوديتهاى تأثير كذار بر نتايج مطالعه هستند. نهايتاً از آنجا كه يزووهشى
تمرين منظم روى تردميل بر سطوح NGF، گيرنده تيروزين كيناز (TrKA) و ف فسفاتيديل اينوزيتول كيناز-ب (Pi3-K)

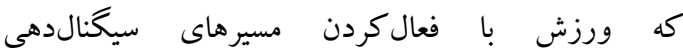
protein mitogen-activated) MAPK/Erk1/2 kinase /extracellular signal-regulated (kinase1/2 باعث افزايش سطوح NGF در گروههاى ورزش ديابتى و ورزش سالم شدهاست(IF). علاوه بر اين دخيلى و همكاران (rara) در مطالعهاى كه به بررسى اثر 9 هفته تمرين استقامتى بر بيان زن فاكتور رشد عصبى در بخش حسى رتهاى با نوروياتى ديابت يرداختند. نتيجه تحقيق اين محققين نشان داد كه 9 هفته تمرين استقامتى به طور معنىدارى باعث افزايش سطوح NGF هم در رتهاى با نوروياتى ديابت و هم در رتهاى سالم شد. يُزوهشخران در اين مطالعه اظهار داشتند كه سطوح NGF در گروه ديابت تمرينى نسبت به گرووه تمرينى سالم بيشتر بوده؛ اما اختلاف بين دو گروه معنىدار نبود كه از دلايل احتمالى اين افزايش را نياز بيشتر به NGF در بخش حسى رتهاى ديابتى نسبت به رتهاى سالم و نيز مضاعف بودن فشار تمرين در كروه ديابت به دليل اختلال و آسيب به اعصاب محيطى دانستند.آنها همجينين عنوان كردند كه ورزش از طريق كاهش سطح كورتيكواسترون و تقويت ظرفيت آنتىاكسيدانى باعث افزايش سطوح NGF

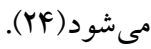
با اين وجود برزگر و همكاران (سوسا) در مطالعهاى بهمنظور بررسى اثرات انواع مختلف تمرينات ورزشى از نوع اجبارى روى نوار گردان، به مقايسه جهار نوع تمرين استقامتى با شدت كم، تمرين تناوبى شديد، تمرين با شدت زياد و تمرين روى سطح شيبدار به مدت هشت هفته يرداختند. نتايج اين مطالعه نشان داد كه در هيج يكك از اين شدتها، سطح عوامل نروتروفيك نسبت به كروه كنترل تفاوت معنىدارى ندارد. محققين در اين مطالعه عنوان كردند كه براى افزايش سطح عوامل نروتروفيك در مغز 


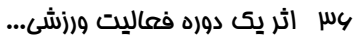

13.Wens I, Keytsman C, Deckx N, Cools N, Dalgas U, Eijnde BO. Brain derived neurotrophic factor in multiple sclerosis: effect of 24 weeks endurance and resistance training. Eur. J. Neurol.2016; 23(6):1028-35.

14.Chae CH, Jung SL, An SH, Park BY, Wang SW, Cho IH, et al. RETRACTED: Treadmill exercise improves cognitive function and facilitates nerve growth factor signaling by activating mitogen-activated protein kinase /extracellular signal-regulated kinase $1 / 2$ in the streptozotocin-induced diabetic rat hippocampus. Neuroscience. 2009; 164(4):1665-73.

15. Chae CH, Jung SL, An SH, Jung CK, Nam SN, Kim HT. Treadmill exercise suppresses muscle cell apoptosis by increasing nerve growth factor levels and stimulating $p$ phosphatidylinositol 3-kinase activation in the soleus of diabetic rats. J Physiol \& Biochem. 2011; 67(2):235-41.

16.Moghadasi M, Edalatmanesh MA, Moeini A, Nematollahzadeh mahani M, Arvin H. Effect of 8 weeks resistance training on plasma levels of nerve growth factor and interlukin-6 in female patients with multiple sclerosis. ISMJ. 2015; 18(3): 527-537.

17.Mirdar Harijani Sh, Musavi N, Hamidian GhR, oliaei HA. Effect of Endurance Swimming Training and Silymarin Treatment on Changes in Liver Apoptotic Index in Pregnant Rats Exposed to Cadmium. JRafsanjanUniv Med Sci . 2014; 13(8): 705-14.

18.Pazhoohan S, Satarian L, Asghari A, Salimi M, Kiani S, Mani A, \& Javan M. Valproic Acid attenuates disease symptoms and increases endogenous myelin repair by recruiting neural stem cells and oligodendrocyte progenitors in experimental autoimmune encephalomyelitis . J Neurodegener Dis. 2013; 13(1), 45-52.

19.Mosayebi G, Ghazavi A, Payani MA. The Effect of Vitamin D3 on the Inhibition of Experimental Autoimmune Encephalomyelitis in C57BL/6 Mice. RJMS.2006; 13(52): 189196.

20.Chae CH, Lee HC, Jung SL, Kim TW, Kim JH, Kim NJ, et al. RETRACTED: Swimming exercise increases the level of nerve growth factor and stimulates neurogenesis in adult rat hippocampus. Neuroscience. 2012; 212:30-7.

21.de Abreu DF, Eyles D, Feron F. Vitamin D, a neuro-immunomodulator: implications for neurodegenerative and autoimmune diseases. PSYCDE. 2009; 34(1):S265-77.

22.Gold SM, Schulz KH, Hartmann S, Mladek M, Lang UE, Hellweg R, et al. Basal serum levels and reactivity of nerve growth factor and brain-derived neurotrophic factor to standardized acute exercise in multiple sclerosis and controls. J Neuroimmunol. 2003; 138(1):99-105.

23.Patel DI, White LJ. Effect of 10-day forced treadmill training on neurotrophic factors in experimental autoimmune encephalomyelitis. Appl Physiol Nutr Metabol. 2013; 38(2):194-9. 24.Dakhili A, Gharakhanlou R, Movaheddin M, Rahmati M, Keshavarz M. The effect of 6 weeks endurance training on gene expression of nerve growth factor in sensory Spinal Cord of rates with Diabetic Neuropathy. IJDO. 2014; 13(3), 44-49.

25.Barzegar H, Vosadi E, Borjian fard M. The effect of different types of exercise training on brain-derived neurotrophic factor in the rat. Sport Physiology. 2015; 6(24):99-108.

26.Hamidi Perchikolaei S.O, Fallah Mohamadi Z, Hajizadeh Moghadam A. The effect of treadmill running with consumption of vitamin D3 on NGF levels in Parkinsonian rat's striatum. Sport Physiology. 2015; 8(29): 91-92. 